\title{
PROBLEMATICS ON SEPARATION OF POWERS THEORY IMPLEMENTATION
}

\author{
Haposan Siallagan \\ Law Faculty of HKBP Nommensen University \\ E-mail: haposan.siallagan@yahoo.co.id
}

\begin{abstract}
Based on theory of powers separation as popularized by Montesquieu, state power is separated into three main branches, namely the legislative, executive and judicial. Theoritically, the theory was always used as a reference in various countries around the world. However, in practice, the theory of separation of powers it is rarely implemented consistently with a variety of considerations. It becomes its own problem regarding the implementation of the powers separation theory. To avoid problems, the theory and practice of the separation system or division of state power must be executed consistently.
\end{abstract}

Keywords: check and balance, state power, separation of power.

\begin{abstract}
Abstrak
Berdasarkan teori pemisahan kekuasaan negara atau teori trias politika sebagaimana dipopulerkan Montesquieu, kekuasaan negara dipisahkan dalam tiga cabang utama, yaitu legislatif, eksekutif dan yudikatif. Secara teori, teori tersebut selalu dijadikan rujukan berbagai negara di dunia. Namun, dalam tataran praktik, teori pemisahan kekuasaan justru sangat jarang dijalankan secara konsisten dengan berbagai pertimbangan. Hal ini menjadi problem tersendiri terkait dengan implementasi teori pemisahan kekuasaan. Agar tidak menimbulkan problem dan perdebatan berkepanjangan, seyogianya berbagai negara di dunia dapat menjaga konsistensi antara teori dan praktik mengenai pemisahan atau pembagian kekuasaan negara yang dijalankan di masing-masing negara.
\end{abstract}

Kata Kunci: checks and balance, kekuasaan negara, pemisahan kekuasaan

\section{Introduction}

The theory of powers separation appears with the main idea to separate the powers of the State in State institutions that separate, including by putting different people as holders and running each of the State power. According with its name, the doctrine of powers separation requires in order that State power is separated into three main branches of State power, that power is shaping legislation, the power running of statute and the powers of the judge over execution of laws. On the basis of separation, then the theory of separation of powers also known with the Triassic Politika theory that in the development historical popularized by Montesquieu. Each of

Janpatar Simamora, "Tafsir Makna Negara Hukum dalam Perspektif Undang-Undang Dasar Negara Republik Indonesia Tahun 1945", Jurnal Dinamika Hukum, Vol. 14 No. 3, the State power is in a position that equal to one power with other powers.

As adduced by Janpatar Simamora ${ }^{1}$ with quoting the view of Friedrich Julius Stahl said that separation of powers is one of the conditions for the existence of formal legal State and is one of the fundamental principles regarding the state organization. ${ }^{2}$ Based on historical records, at first, the emergence of the idea or theory of separation of powers meant in order to prevent the occurrence of arbitrariness or arbitrary acts committed by the King or ruler.

In the development of application or implementation, an understanding of the theory of powers separation in various countries, conducted with the model and characteristics vary bet-

September 2014, Purwokerto: Fakultas Hukum Universitas Jenderal Soedirman, page. 552.

2 Ibid, page 553. 
ween one country with other countries, it can even be said that the theory of powers separation raises a wide range of understanding in various law constitution, such as the understanding of the legislative powers delegation, the independence of the judicial power, the responsibility of the Executive Body Shaperagainst the legislation, the right of the test material and so on. This encourages the emergence of various modifications against the theory of separation of powers itself.

Later, the separation of powers based on the principle of Triassic politika is considered not principle again ${ }^{3}$ and each country runs the theory of separation of State power with a different model. For example, in the United Kingdom there is a concentration of power in the legislative body in some sense superior to on the Executive and the judicial. Therefore, the emerging disagreement description Montesquieu about separation of powers in the United Kingdom. In addition, other notions from the theory of powers separation, especially between the legislative and Executive, is associated with a physical separationn between the double-sense or law of persons and the nature of the separation or independence of function.

The notion of "separated" in this context can be defined legally, keep an eye on each other so could run mutual supervision. In addition, the theory of powers separation may put on the understanding that the activities separation of legislative, executive and judiciary, indistinguishable in the sharp one over the other. In a number of countries, including Indonesia, can be said to define the theory of powers separation by means of this term. Among one powers with the others do not distinguish in sharp, for a possible power run other powers. For example, although the Executive Branch has the primary authority in carrying out the legislation, however, the Executive is also possible to participate in the process of the laws formation where the power is the principal legislative authority.
The pattern of this kind of application is more often referred to as a form of powersharing, not the separation of powers. Nevertheless, almost all countries always refer to the powers separation theory of the State as popularized by Montesquieu in order to regulate the State power. It's just that in the implementation of landscape, the theory is not always run in pure and inconsistent. Each country trying to translate the State powers separation theory in accordance with the level of needs of each country. Based on these conditions, may be relevant to be discussed related to how the actual implementation of the theory of powers separation in General? and if found the presence of consistency and alignment between theory and the powers separation theory implementation itself? A number of these being reviews are important in the following discussion.

\section{Disscussion}

The History of Separation Powers Emergence Theory

Based on historical records of the middle ages, namely between the 14th to 15th century, the powers of Government in Western Europe centered on the King's hand. ${ }^{4}$ In the run of these powers, the King a lot of actions that leads to arbitrary deeds. In order to prevent arbitrariness, then later taken from the hands of some powers, especially the powers relating to justice, where the power of Justice is handed over to the judiciary. In the 17th century and in the 18th, appears the concept suggested that the power to make any regulation must be taken and separated from the hand of the King. Power to make regulations must be submitted to a State agency that stands alone and separate from the power of the King. Because of that, then makes the birth of the powers separation theory. The powers separation theory is essentially a theory of governance that aim in order to protect freedom and to facilitate good governance with dividing

Muntoha, “Demokrasi dan Negara Hukum”, Jurnal Hukum, Vol. 16 No. 3, Juli 2009, Yogyakarta: FH Universitas Islam Indonesia, page 386

Khumaidi, "Pemisahan dan Pembagian Kekuasaan dalam Konstitusi Perspektif Desentralisasi," Jurnal Kebangsaan, Vol. 6 No. 1, September 2012, Pasuruan: Universitas Yudharta, page 16. 
or separating the specialization of State power. ${ }^{5}$ The development of the powers separation concept, if analyzed theoretically, began to be developed in line with the opinions expressed by John Locke. According to John Locke, the power in the country is divided into three parts: first, the power to form laws (legislative); second, the authority carrying out the Act (executives); and third, the powers. ${ }^{6}$

Follow up on what was expressed by John Locke, an expert in France law named Montesquieu put forward his views on State power. Montesquieu points out that State power can be divided in three major powers should be separated, that are: first, the legislative power, that power in shaping laws; second, the Executive power, that power in an exercise or enforce the legislation; and third, the judicial power, that power in the exercise of judicial power or often also referred to as judicial power. ${ }^{7}$ Thought this was later known as the powers separation theory or Triassic politika theory.

In principle, it can be said that the separation of powers meant to prevent arbitrariness and ensure the creation of an independent judicial authority and free from the influence of other powers. It later became one of the country's law. ${ }^{8}$ However, it should be affirmed that the theories of Montesquieu didn't intend for the separation of government institutions without control over the actions of one against the other. On the basis of that, then it appears the theory or principle of checks and balances, so that it can be said that the theory of checks and balances is a part or a complement of the theory of separation of powers.

The designers of United States constitution for example, implement the freedom of the judiciary by setting the system of checks and balan- ces, in which none of the branches of Government may be cutting off itself from the other branches of Government control. Based on this system, no one branch of Government has the dictatorial power or it can seize the power of the other branches. In terms of powers separation with checks and balances system, in summary it can be concluded that there is no power which is absolutely apart from other powers. The issue is whether this applies also to the power of Justice? This is still an ongoing controvertion until now.

\section{The Interconnectedness of The Powers Sepa- ration Theory with Checks and Balances Prin- ciple}

During this time, although it is no longer a fixed, the United States has been always considered a country that consistently run theory of Triassic politika. ${ }^{9}$ Hans Kelsen describes this situation by declaring that the principle was the basis for the Triassic politika United States Constitution and is considered a staple element of democracy. This principle is formulated by the Supreme Court, that is all powers that mandated, either to the Government or to the Government of the State, divided into three parts, namely the Executive, legislative and judicial powers or of Justice. Tasks that are appropriate for each branch of Government is provided separately to some State organizers.

A staple for success of this system implementation is the body which has been given power may not disrupt or interfere with the powers that have been given to other agencies. Each restricted to carry out what became of his power. United States attempt to order, as set forth in its Constitution, establishing the President as a body which organizes the Executive power; legislative power is vested in the Congress, which consists

Agus Wahyudi, "Doktrin Pemisahan Kekuasaan: Akar Filsafat dan Praktek", Jurnal Jentera Hukum, Vol. 8 No. 3 Maret 2005, Jakarta: PSHK, page 1.

6 Emmelia Tricia Herliana, "Penerapan Konsep Trias Politica pada Morfologi dan Tipologi Kota Washington DC dan Canberra", Jurnal Arsitektur Komposisi, Vol. 10 No. 4 Oktober 2013, Yogyakarta: FT Universitas Atma Jaya, page 269.

7 Wahyu Wiriadinata, "Kedudukan dan Independensi Kejaksaan dalam Undang-Undang Dasar Negara Republik Indonesia Tahun 1945”, Jurnal Legislasi Indonesia, Vol. 10 No.

1, Maret 2013, Jakarta: Direktorat Jenderal Peraturan Perundang-undangan Kementerian Hukum dan HAM RI, page 11.

8 Hadi Supriyanto, "Pemisahan Fungsi Kekuasaan Eksekutif dan Yudikatif," Jurnal Legislasi Indonesia, Vol. 1 No. 1 Juli 2004, Jakarta: Direktorat Jenderal Peraturan Perundang-undangan Kementerian Hukum dan HAM RI, page 1.

9 Hananto Widodo, "Politik Hukum Hak Interpelasi Dewan Perwakilan Rakyat Republik Indonesia", Jurnal Rechtsvinding, Vol. 1 No. 3, Desember 2012, Jakarta: BPHN, page 420 . 
of representatives House and the Senate; and the judiciary power is exercised by the Supreme Court. As for the President who held the position for four years can not be brought down by Congress, instead, Congress can't be dissolved by the President. The President or Ministers may not concurrently be a member of Congress. As for the Supreme Court, has the position of which is free and the judges appointed to lifetime tenure for being of good character.

Although the powers that have been allocated to some of United States Government system institutions, but in fact also apply what is called checks and balances (supervision and equalization), for example through the authority of judicial review by the judiciary. The President was authorized to veto a bill that has been accepted. A presidential veto can be canceled if in both the Senate and Assembly House that is there are $2 / 3$ of the votes were against the veto.

The Supreme Court can do a "check" against the ruling of the legislature and Executive through judicial review. The judicial review idea emergence was intended to obey the existing laws and regulations against the legal norms contained in the regulations in order, in particular, its top level in accordance with the constitution. ${ }^{10}$ Members of the Supreme Court who was appointed to the post of a lifetime can be dismissed by Congress, if it turns out to have been doing criminal acts. The President can incur impechment by Congress. In the appointment of the President authority post, such as becoming Chief Justice, Ambassador, or Ministers who are considered occupied an important position, the Senate could intervene.

The practice of the United States's attempt to demonstrate how difficult the theory of Triassic politika with separation of powers, this thesis was actualized in reality condition. Transmission of one branch with more difficult were shunned, even one of the branches of power has several functions according to the ideas of Mon-

10 Janpatar Simamora, “Analisis Yuridis Terhadap Model Kewenangan Judicial Review di Indonesia", Jurnal Mimbar Hukum, Vol. 25 No. 3, Oktober 2013, Yogyakarta: Fakultas Hukum Universitas Gadjah Mada, page 389. tesquieu is absolutely not allowed. As a consequence of the separation occurrence between the branches of power are fragmentary, it needs to be rooted in the principle of checks and balances so that the relationship between one institution with other institutions can mutually offset in equity and equality as well as to avoid the concentration of power in one institution. ${ }^{11}$ This is where the look of how the connectedness between the theory of separation of powers or trias politika with the principle of checks and balances.

In the context of Indonesia, in particular in the Constitution of 1945 after the change, the checks and balances principle application can be seen in some of the following: first, the supervisory functions of the parliament are seen in terms offiling a proposal to parliament to dismiss the President with reason, with the first get legal consideration of the Constitutional Court. In addition, the function of supervision is the next in the form of House approval if the President declares war, make peace and treaties with other countries. Other forms of supervision is in the form of consideration when the President will appoint an Ambassador, received the Ambassador of another country, placement and gave amnesty and abolition. Secondly, the control function is owned by the president of representatives house was against the president were given the right to submit the bill, the president was given the rights to authorize or not authorize a bill that had already been discussed along with representatives, legal rights for a while in a state of crunch that forced government regulations specify a substitute bill that should shapethe legislation. Thirdly, in the field of the judiciary the President given the right with consideration of the Supreme Court (MA) to assign the granting of pardons, abolition and Amnesty, the President also has the authority to assign a Chief Justice and three judges set the Constitution at the Constitutional Court (MK). The fourth, members of the house of

11 Hezky Fernando Pitoy, “Mekanisme Checks and Balances antara Presiden dan DPR dalam Sistem Pemerintahan Presidensial di Indonesia”, Jurnal Lex et Societatis, Vol. II No. 5, Juni 2014, Manado: FH Universitas Sam Ratulangi, page 31 . 
representatives gave approval against the prospective Chief Justice's proposed Judicial Commission (KY) and set the three judges on the constitutional court. Fifth, the associated Power of Justice. The powers of the Judiciary, both in terms of substance as well as this Administration has been establilished and is independent. MA was given the authority to conduct a judicial review against the laws and regulations under the act against the act. As for the Constitutional Court authorized to test act constituting the legislative joint products in this DPR and the President against the Constitution. Related to the authority of the court in testing the act against the constitution, along with the inclusion of the back TAP MPR as one type of legislation with the position a notch below the constitution and a notch above the law, according to Janpatar Simamo$\mathrm{ra},{ }^{12}$ that provision confirms that indeed it is not possible to mention the birth of a legislation degree their hierarchy is a notch below the constitution and a notch above the law.

\section{Problematics on Separation of Powers Theory Implementation}

Despite so many countries that recognizes the efficacy of powers separation theory in the lay State power in their respective countries, but the reality shows that it is not always in line with what is practiced in many different countries of the world. Even later, many circles which assume that indeed the powers separation theory is no longer relevant in the modern State. Nevertheless, the powers separation theory thus always made reference in discussing about the State power. That is, there is a difference in terms of theory and practice in respect of the powers separation theory existence. In landscape theory, the powers separation theory has always been the citation Foundation, even often used as reference material in a variety of scientific studies. But in practice, the theory of Triassic politika thus often abandoned and not even run consistently.

12 Janpatar Simamora, "Problem Yuridis Keberadaan TAP MPR dalam Hierarki Peraturan Perundang-undangan Menurut Undang-Undang Nomor 12 Tahun 2011", Jurnal
The framers Constitution unanimously agreed that the Constitution made for an independent Indonesia is not based upon the theory of trias politica or powers separation theory. This can be seen clearly, one of them from a statement which stated that basic Soepomo and the form of the order of a country is closely connected with the historyof legal and social institutions of the country. If examined further, before the change of Constitution, the terms relating to the theory of separation of powers can be found in the Constitution, that is legislative power and executive power. The terms listed in the explanation when describing the position of the President of the Republic of Indonesia. Meanwhile, the term "judicial power" not found. However the equivalent word with the term can be found in article 24 Constitution 1945, namely the powers of the judiciary. Constitution set six State agencies, each of which has the power granted by the Constitution. One agency is designated as the highest State institution, namely MPR and the five so called high State institutions, namely the DPR, President, MA, DPA, and BPK.

The provisions of article 1 paragraph (2) of the Constitution states that sovereignty is in the hands of the people and carried out entirely by the MPR. The MPR has the power to set Constitution and the outlines of the bow country, and changing the Constitution. This is a power to the MPR to create conditions which are legislative. Other powers was vote for President and Vice President. In relation to the powers of legislative, article 5 paragraph (1) of the Constitution stipulates, the President holds the power to form the Act with the approval of the DPR. In the Constitution 1945, the powers of the formation of the Act is on the President and the power should be exercised with the consent of the Parliement.

Related with the powers of Judiciary, in accordance with Article 24 paragraph (1), performed by MA and other judicial body according to law. MA in further development, have power test, which is in the knowledge of the law of attempt is called judicial review. MA has the right

Legislasi Indonesia, Vol. 10 No. 3, September 2013, Jakarta: Direktorat Jenderal Peraturan Perundang-undangan Kementerian Hukum dan HAM RI, page 227. 
to test the material against the regulations of the Act. Furthermore, DPA is regulated in article 16 paragraph (2), the article set, this Council is obliged to give answer to the question the President and has the right to advance the proposal to the Government. Meanwhile, article 23 paragraph (5) establishes the existence of the Agency Financial Inspectors who job examining the financial responsibility of the State. The results of examination of the bodies notified to Parliament.

The powers of Republic of Indonesia President regulated in chapter III with the title Government Negar, that is Article 4 paragraph (1), 5, 10-15, and article 22 paragraph (1). Article 4 paragraph (1), President of the Republic Indonesia holds the power of Government according to the basic law. Stated in the explanation that the President is the head of the Executive power in the Country.

The provisions of article 14 establishes that the President give clemency, Amnesty, abolition, and rehabilitation. The position of President, in addition to as head of State, as well as head of Government. If it is associated with article 4 paragraph (1) of the Constitution, then it can be said, the head of State holds the power of Government according to the basic law. In other words, according to the Constitution, the head of State of RI is host of the Government.

The explanation above shows that Indonesia's attempt in the system, the branches of that power is not concentrated on one hand, but carried out by different agencies. The existence of a body that in addition to exercise power typically also carry out other powers and the tangle branches power relations existence between these entities gives the sense that the theory of Triassic politika not applied absolutely.

Essentially, the powers separation theory is seen irrelevant to be applied as a whole. The development needs of the country's attempt to have created the function of State power cannot run independently by different institutions. The relationship between the branches of State po- wer may not run without the existence of a link between one branch of power with other branches of power. Because of the loss of the idea of Triassic politika nowadays, there is an attempt touse the new terminology that is approaching the fact about the third branch of power.

There are more inclined to use the term ' rule-making function to replace the term legislative functions in an effort to avoid the sense as if legislation that was justcreated by the legislature. In addition, the term also frequently asked questions is the term rule application function replaces the term function of the Executive power and the term rule adjudication function as another term of the powers of the judiciary or judicial. ${ }^{13}$

As for the present theory is meant to answer the weaknesses or deficiencies contained in powers separation theory is a theory of power $\mathrm{Di}$ vision. Based on power Division theory, the power of a country are not separated, but ultimately made existence of linkages possible or relationships between one branch of power with other branches of power. Good powers of Executive, legislative and judiciary it is possible to have relationships in running each of those powers. Surely the relationship is not addressed in order to intervene between the branches of State power, but in order to create the execution of State power that is effective and efficient.

\section{Closing \\ Conclusion}

Although the existence of powers separation theory or trias politika always made reference to fundamental in discussing about the power of the State, but in general, implementation of the powers separation theory in a number of countries In recent times tends to be more modified according to the needs of each country. In addition, not found the presence of consistency and alignment between theory and implementation of powers separation theory itself, because the theory in question no longer run in pure and inconsistent, even later, more inclined to apply

13 Syofyan Hadi, “Fungsi Legislasi dalam Sistem Pemerintahan Presidensil (Studi Perbandingan Indonesia dan Amerika 
the Division theory power in an effort to answer the weaknesses of powers separation theory.

\section{Suggestion}

Need better alignment between theory and practice associated with the State powers separation theory for the sake of national consistency. The State powers separation theory, when it is no longer implemented consistently with a variety of considerations, such as by using the theory of power Division, then need for honesty attitude not to always refer to the powers separation theory in the theoretical studies for the creation of consistency between theory and practice.

\section{References}

Hadi, Syofyan. "Fungsi Legislasi dalam Sistem Pemerintahan Presidensil (Studi Perbandingan Indonesia dan Amerika Serikat". Jurnal Ilmu Hukum. Vol. 9 No. 18 Pebruari 2013. Surabaya: Universitas 17 Agustus;

Herliana, Emmelia Tricia. "Penerapan Konsep Trias Politica pada Morfologi dan Tipologi Kota Washington DC dan Canberra". Jurnal Arsitektur Komposisi. Vol. 10 No. 4 Oktober 2013. Yogyakarta: FT Universitas Atma Jaya;

Khumaidi, "Pemisahan dan Pembagian Kekuasaan dalam Konstitusi Perspektif Desentralisasi." Jurnal Kebangsaan. Vol. 6 No. 1 September 2012. Pasuruan: Universitas Yudharta;

Muntoha, "Demokrasi dan Negara Hukum". Jurnal Hukum. Vol. 16 No. 3 Juli 2009. Yogyakarta: FH Universitas Islam Indonesia;

Pitoy, Hezky Fernando. "Mekanisme Checks and Balances Antara Presiden dan DPR dalam Sistem Pemerintahan Presidensial di Indonesia”. Jurnal Lex et Societatis. Vol. II No.
5 Juni 2014. Manado: FH Universitas Sam Ratulangi;

Simamora, Janpatar. "Analisis Yuridis Terhadap Model Kewenangan Judicial Review di Indonesia”. Jurnal Mimbar Hukum. Vol. 25 No. 3 Oktober 2013. Yogyakarta: Fakultas Hukum Universitas Gadjah Mada;

....... "Problem Yuridis Keberadaan TAP MPR dalam Hierarki Peraturan Perundang-undangan Menurut Undang-Undang Nomor 12 Tahun 2011." Jurnal Legislasi Indonesia. Vol. 10 No. 3 September 2013. Jakarta: Direktorat Jenderal Peraturan Perundangundangan Kementerian Hukum dan HAM $\mathrm{Rl}$;

Simamora, Janpatar. "Tafsir Makna Negara Hukum dalam Perspektif Undang-Undang Dasar Negara Republik Indinesia Tahun 1945". Jurnal Dinamika Hukum. Vol. 14 No. 3 September 2014. Purwokerto: Fakultas Hukum Universitas Jenderal Soedirman;

Supriyanto, Hadi. "Pemisahan Fungsi Kekuasaan Eksekutif dan Yudikatif." Jurnal Legislasi Indonesia. Vol. 1 No. 1 Juli 2004. Jakarta: Direktorat Jenderal Peraturan Perundangundangan Kementerian Hukum dan HAM $\mathrm{RI}$;

Wahyudi, Agus. "Doktrin Pemisahan Kekuasaan: Akar Filsafat dan Praktek". Jurnal Jentera Hukum. Vol. 8 No. 3 Maret 2005. Jakarta: PSHK;

Widodo, Hananto. "Politik Hukum Hak Interpelasi Dewan Perwakilan Rakyat Republik Indonesia”. Jurnal Rechtsvinding. Vol. 1 No. 3 Desember 2012. Jakarta: BPHN;

Wiriadinata, Wahyu. "Kedudukan dan Independensi Kejaksaan dalam Undang-Undang Dasar Negara Republik Indonesia Tahun 1945". Jurnal Legislasi Indonesia. Vol. 10 No. 1 Maret 2013. Jakarta: Direktorat Jenderal Peraturan Perundang-undangan Kementerian Hukum dan HAM RI. 